\title{
Contribution to the Logistic Evaluation System in the Transportation Process in Santo Domingo, Ecuador
}

\author{
Rodobaldo Martínez-Vivar (iD, Alexander Sánchez-Rodríguez (iD), Reyner Pérez-Campdesuñer (iD), \\ Gelmar García-Vidal iD \\ Universidad Tecnoloógica Equinoccial (Ecuador)
}

rodobaldo.martinez@ute.edu.ec, alexander.sanchez@ute.edu.ec,reyner.perez@ute.edu.ec,gelmar.garcia@ute.edu.ec

Received: August 2017

Accepted: February 2018

\begin{abstract}
:
Purpose: The objective of the present research is to design and apply a methodology to evaluate the logistics system in the transportation process in a base vehicle pool, which contributes to decrease the costs of distribution and to increase the performance of the logistics system of the organization.

Design/methodology/approach: The proposal of a holistic technology for the management of this process is carried out, which integrates indicators and tools that improve control and decision-making activities in this area.

Findings: The application of the procedure developed in the selected organization contributed to the identification of deficiencies related to the availability of the equipment and the needs of the clients, the low technical availability of the automotive plant, the low utilization of the capacity of the freight vehicles, the absence of a plan of measures to diminish the empty routes of the transport and the overconsumption of fuel due to the accomplishment of extra trips. Aspects that contributed to the redesign of some of the main functions of physical distribution such as itinerary planning, selection of means of transport and analysis of operating indicators, aspects that favored the optimization of the number of trips and, consequently, the adequate use of the equipment and the loads to be transported, observing a saving of $15 \%$ in the fuel consumption per load transported.
\end{abstract}

Originality/value: The originality of the present research lies in the combination of different theories and techniques that contribute from a holistic approach to the logistics evaluation of the transportation process, facilitating the optimization of transportation requirements, its operation and maintenance.

Keywords: logistic system, evaluation methodology, transportation process

JEL Codes: L23, L91, L97.

\section{Introduction}

The need to study logistics management is acknowledged to be important, highlighting several authors, who in some way have contributed to the development of this science in areas such as the positioning of the production system, design and study of production processes and the design of services and production plans, the allocation of resources, among other aspects that are of vital importance, while also agreeing on the business operation of creating a total system to manage the flow of information to achieve an opportunity, and thus become competitive companies with capacity for innovation to increase the value of products and customer satisfaction (Chang \& Lin, 2016; Ayala-Bécquer, Bustillo-González \& Sánchez-Fernández, 2001; Ballou, 1991; Altendorfer \& Zsifkovits, 2016; 
Fahimnia, Reisi, Paksoy \& Özceylan, 2013; Chase, Jacobs \& Aquilano, 2009; Swink, Melnyk, Cooper \& Hartley, 2014; Heizer \& Render, 2009; Krajewski, 2012; Magee, 1968; Carrasco, Mataix, \& Carrasco-Gallego, 2017; Stoner, 1996; Raza, Lang \& Jedermann, 2017; Cespón-Castro \& Auxiliadora-Amador, 2003; Vélez, 1996; Lee \& Lam, 2012; Afonso \& Santana, 2016; Movahedipour, Yang, Zeng, Wu \& Salam, 2016; Mimouni, \& Abouabdellah, 2016; Martínez-Vivar, Sánchez-Rodríguez, García-Vidal \& Pérez-Campdesuñer, 2016).

In this context, logistics evaluation is considered to be of great importance, contributing to determine if the business processes are being adequately met, and to detect the main problems that may exist within the automotive pool, using indicators that measure efficiency and efficiency, such as level of service that is rendered and therefore the one perceived by the client, being considered as a primary factor in the economic development of the organization.

The present investigation involves an analysis of the different strategies used in Rancho Mary Base vehicle pool, recognized for delivering quality products, which has presented some difficulties in the distribution system. Based on the logistic evaluation, it has been possible to determine that it does not have a preventive and corrective maintenance plan for its automotive pool, causing non-compliance at the time of delivery of the products, causing returns and dissatisfaction on the part of the customers. Likewise, it has been detected that the distribution routes are not planned, arriving to verify informality by the workers who are in charge of the distribution of the products in the units of the company, that are used for personal purposes not programmed in the work schedule.

The elements discussed above show the existence of both theoretical and practical contradictions, since there is a need to organize the transport system in the company under study and the lack of a methodological tool that contributes to the implementation. Therefore, the objective of this paper is to design a methodology to evaluate the logistics system in the transportation process in the Rancho Mary Base vehicle pool.

\section{Theoretical Analysis}

From a logistical point of view, any reflection on modern business management is basically framed in two fundamental ideas: on the one hand the business logistics management and, on the other, the opportunities that the technology offers. To illustrate the logistics management, it is interesting to make a series of considerations about its scope, its role and its integrative character, a question that can be made on the basis of three concepts: the definition of logistics management, customer orientation and cost analysis towards permanent improvement of the system.

On the other hand, logistics involves four subsystems recognized in the literature, among which are listed: Procurement, production, distribution and reuse, which in their holistic operation contribute to the performance of the business system (Chang \& Lin, 2016; Ayala Bécquer et al, 2001; Ballou, 1991; Altendorfer \& Zsifkovits, 2016; Fahimnia et al, 2013; Chase et al, 2009; Swink et al, 2014; Heizer \& Render, 2009; Krajewski, 2012; Magee, 1968; Carrasco et al, 2017; Stoner, 1996; Raza et al, 2017; Cespón-Castro \& Auxiliadora-Amador, 2003; Vélez, 1996; Lee \& Lam, 2012; Afonso \& Santana, 2016; Movahedipour et al, 2016; Mimouni, \& Abouabdellah, 2016; Martínez-Vivar et al, 2016).

In particular, the function of distribution and transport is a key activity of logistics, influencing two essential aspects: the utility of place and time, which means having the goods at the place and time needed. According to this criterion, there is a great variety of concepts around this important activity, being one of the most used both in practice and in the academic context contributed by Cespón-Castro and Auxiliadora-Amador (2003), who refers to transport: as a key activity to logistics, whose function is the transfer of materials and goods to points of consumption, in addition to adding value of time and place.

Under this criterion, it could be stated that the transport system (TS) constitutes the set of modes, means and facilities or infrastructure, which serve as a material basis for the execution, by man, of transportation activities, through the economic and juridical relationships established in an organization (Lee \& Lam, 2012; Afonso \& Santana, 2016; Movahedipour et al, 2016; Mimouni \& Abouabdellah, 2016; Martínez-Vivar et al, 2016). In the 
previous approach the elements that compose this system materialized in the material base and the economic and legal relations.

In this way excel authors such as Chang and Lin (2016), Ayala-Bécquer et al (2001), Ballou (1991), Altendorfer and Zsifkovits (2016), Fahimnia et al (2013), Chase et al (2009), Mimouni and Abouabdellah (2016), MartínezVivar et al (2016), who agree that transportation decisions belong to both the operational and tactical levels; With an emphasis on the tactical level when selecting the transport company with which cooperation and operational ties will be established, when deciding the mode of transport to be used. For both decisions should consider the impact that will occur in costs. The most economical mode of transport does not necessarily result in lower costs for the entire supply chain, usually cheaper transport modes have longer delivery times and the minimum quantities to be transported are higher, leading to high levels of inventory along the logistics channel.

This presupposes the preference for fast delivery modes for products with a high index of the value of the goods against the weight, where inventory levels are important costs, and on the other hand delivery modes of transport are preferred for products with a low index of value against weight and for which, it is less important to reduce inventory costs.

It is a serious mistake to ignore inventory costs when deciding which mode of transport to use, since a wrong decision can reduce the performance of the supply chain. Likewise, the analysis that is presented is valid when the decision to select a specific means of transport is presented, in the presence of several alternatives.

This is why the present article tries to develop a methodology that contributes to the design of a logistics assessment system, in the transport processes, particularly in the object of selected practical study. This methodology systematically addresses an integrative approach by fully assessing the distribution process. It also incorporates a set of indicators that contribute in its analysis to the decisions related to the subcontracting, purchase and maintenance of vehicles dedicated to transportation.

\section{Methodology}

Before beginning to detail the phases and steps of the methodology for the evaluation of the logistics system in the transport process, the organization should be characterized, emphasizing the logistic distribution system.

In this point of the characterization will be provided with information on the activity of the company as its main supplier, characterization of human resources, mission, vision, objectives and values.

The characterization of the logistic distribution system aims to recognize the real problems in the functioning of the distribution subsystem as:

- Distribution destinations

- Distribution equipment

- $\quad$ Products to be distributed

\subsection{Phase I. Diagnosis of the Transport Function within the Distribution System}

Step 1. Service level evaluation. In order to carry out the diagnosis of the physical distribution function, it is necessary to start from an evaluation of the level of service that is provided and perceived by the customer, which can be evaluated from three points of view.

- The level of service offered

- The level of service provided

- The level of service provided by the customer

Therefore, the company's main objective is to ensure the quality of the service offered and the perceived service. This measurement is made from indicators that are collected within the company, for example, internal data about the quantity of orders that have been delivered out of date, records of unpaid quantities and defective items, calculated as follows. 


\begin{tabular}{|c|c|}
\hline Service Level & Formula \\
\hline Term & Number of orders out of time / total orders \\
\hline Quantity & Number of incomplete orders / total orders \\
\hline Quality & Number of defective items / total items \\
\hline
\end{tabular}

Table 1. Service level evaluation

For the calculation of the reliability of the service level provided by the company, the following formula shall be used:

$$
\mathrm{F}=\Pi\left(1-\frac{C F}{N}\right) *\left(1-\frac{C T}{N}\right) *\left(1-\frac{C P}{N}\right) * 100 \%
$$

It is: F: Reliability; CF: Number of failures in term; CT: Quantity of failures in volume; CP: Number of quality failures; N: Total observations.

In order to calculate the level of service perceived by the customer, a survey will be conducted on a sample of customers, which will evaluate fundamental aspects that will be compared with the data obtained in the level of service, in order to know the gap that exists between the two levels to take the necessary corrective actions.

Step 2. Evaluation of the main efficiency indicators. Several indicators are now needed to measure efficiency. In this research will be carried out the specific distribution activity that require the current organizations within the distribution activity specifically to external transformation.

Technical indicators: These are those that are related to the technical characteristics of means of transport, consumption standards of these, needs, compliance and quality of repairs and maintenance.

Economic indicators: These are related to the planning of transport production and its results, highlighting the financial status of the activity and the expenditures of resources consumed in its execution.

Operational indicators: Includes the set of indicators required for the organization of the transportation process, due to its high incidence of transportation.

Step 3. Checklist evaluation. To complete the evaluated one will be necessary the application of a checklist appropriate to the activity of transport, obtained by the department of warehouse of the organization.

The application of these checklists will lead to the main differences in the management of this subsystem, activities that are not carried out and must be carried out. This analysis will serve as a basis for the next phase of the methodology, the analysis and design of the different transport functions.

\subsection{Phase II: Evaluation of the Transport Function within the Distribution System}

Its objective is to evaluate the fundamental activities within the subsystem and if necessary to implement a design that improves the operation of the transport within the distribution.

Step 1. Definition of itineraries. The problem of distributing one or several products to several points through multiple possible routes, depending on the distances between them and the distance from each one to a distribution center, is a typical problem in the field of logistics. However, the selection of the method to be applied will depend on the level of complexity, in the present investigation two methods will be applied: the Sweep, which is included within the error test group, and the Traveler Agent method, considered within the called heuristics (Cespón-Castro \& Auxiliadora-Amador, 2003).

Step 2. Determination of the need for means of transport. Transportation represents a major element within the organization. For an adequate performance in determining the number of trips to be made or means of transport to guarantee the distribution and supply of a purchase order of the customer or final consumers.

There are different aspects that must be taken into account during the organization of the means of transportation, such as the characteristics of the means and the load. In the case of the latter it is necessary to 
know: quantity to be transported $(\mathrm{Q})$, volume of the unit $(\mathrm{Pb})$, coefficient of utilization of the useful volume of the space $(\mathrm{Km})$. As for the means of transport, the static load capacity (q) and volumetric capacity (CW) must be known.

Step 3. Transportation Balance. It is necessary to start from the knowledge of the amount of equipment that will be needed for the transportation of the goods and of the transportation capacity that the organization has, decisions will be made regarding the contracting of these services, or if it is necessary to acquire a greater park of equipment to assume in case the amount of equipment that is needed is greater than the capacity with which it is available.

At the end of the evaluation of each of the phases discussed above, a summary of the main deficiencies detected will be carried out and measures will be projected to solve them. The last phase of this procedure is to perform a new evaluation of the subsystem from the implementation of the proposed measures.

Step 4. Proposal for solutions. In this phase, given the developed diagnosis, a set of measures is proposed that will contribute to the solutions for the improvement of the logistical process of transport.

\subsection{Phase III: Implementation and Adjustment}

Objective: In this phase the implemented solutions will be implemented and the necessary adjustments will be made that contribute to the good operation of the system.

In this phase, the level of service perceived by customers will be recalculated and if it coincides with the level of service expected then the standards will be raised within the distribution policy, and thus contribute to the achievement of a better performance by the organization. However, if the service level still does not meet the customers' expectations then the complete subsystem diagnosis will be resumed, thus showing its fundamental characteristic in continuous improvement.

\section{Results}

Characterization of the organization.-The "Rancho Mary" Company, founded in 2001 at the proposal of the company PRONACA, works as a distributor of the balanced products available at that time. It is characterized by being a transfer yard and have the exclusivity of the mega distribution of balanced food of the company PRONACA in the lines: pigs, cattles, pets, horses and organic fertilizers, this being its only supplier.

As mentioned above, Rancho Mary is responsible for the distribution of balances and fertilizers in different places around Santo Domingo de los Tsáchilas, below are the distances and the demand for each route.

Regarding the products to be distributed, it is known that Rancho Mary is responsible for the distribution of balanced products for cattle, horses, pigs, pets and organic fertilizers, each of these bags have a weight of $45 \mathrm{~kg}$, which is shown in the following table of demand of the different places of Santo Domingo and the neighboring towns (see Table 2).

In terms of distribution equipment, the Table 3 shows the equipment used by the company for sale and distribution of the products. 


\begin{tabular}{|c|c|c|c|c|c|c|c|}
\hline \multirow[b]{2}{*}{ Destinations } & \multicolumn{5}{|c|}{ Demand (Tons) } & \multirow{2}{*}{$\begin{array}{l}\text { Total } \\
\text { Demand } \\
\text { (Tons) }\end{array}$} & \multirow{2}{*}{$\begin{array}{l}\text { Number } \\
\text { of trips (trips } \\
\text { per year) }\end{array}$} \\
\hline & Cattle & Horses & Pigs & Pets & $\begin{array}{l}\text { Organic } \\
\text { Fertilizers }\end{array}$ & & \\
\hline Santo Domingo & 453 & 25 & 1490.00 & 156 & 50 & 2174.00 & 832 \\
\hline La Catorce & 196 & 5 & 341.60 & 80 & 40 & 662.60 & 104 \\
\hline Patricia Pilar & 92 & 16 & 945.15 & 90 & 38 & 1181.15 & 104 \\
\hline Granjas & 650 & 12 & 986.00 & 63.1 & 60 & 1771.10 & 520 \\
\hline El Carmen & 685 & 19 & 1169.20 & 62 & 25 & 1960.20 & 156 \\
\hline La Concordia & 285 & 6 & 1058.00 & 95 & 18 & 1462.00 & 104 \\
\hline Alluriquín & 195 & 1 & 58.00 & 45 & 30 & 329.00 & 208 \\
\hline San Gabriel & 96 & 1 & 85.90 & 1 & 20 & 203.90 & 208 \\
\hline Santa María del Toachi & 197 & 10 & 128.80 & 2 & 15 & 352.80 & 208 \\
\hline Valle Hermoso & 101 & 5 & 170.83 & 1 & 8 & 285.83 & 104 \\
\hline La Unión & 98 & 8 & 185.96 & 1 & 3 & 295.96 & 104 \\
\hline San Jacinto & 50 & 2 & 96.30 & 1 & 5 & 154.30 & 104 \\
\hline Nuevo Israel & 30 & 2 & 35.90 & 0.5 & 2 & 70.40 & 104 \\
\hline Total & & & & & & 10903.24 & 2860 \\
\hline
\end{tabular}

Table 2. Demand according to destination

\begin{tabular}{|c|c|c|c|c|c|c|}
\hline $\begin{array}{c}\text { License } \\
\text { plate }\end{array}$ & $\begin{array}{c}\text { Capacity } \\
\text { (Tons) }\end{array}$ & Year & Model & $\begin{array}{c}\text { Fuel Tank } \\
\text { (Liters) }\end{array}$ & $\begin{array}{c}\text { Fuel } \\
\text { Consumption } \\
\text { in City } \\
(\mathrm{L} / 100 \mathrm{~km})\end{array}$ & $\begin{array}{c}\text { Fuel } \\
\text { Consumption } \\
\text { in Road } \\
(\mathrm{L} / 100 \mathrm{~km})\end{array}$ \\
\hline PLQ0853 & 4000 & 2006 & Canter 4.0 Ton & 100 & 10.9 & 9.7 \\
\hline PTB0776 & 6000 & 2007 & Gh1 Jmua & 200 & 12.9 & 10.9 \\
\hline PCB7952 & 4000 & 2012 & Fsr $34 n$ Truck 2p & 200 & 12.9 & 10.9 \\
\hline JBA5567 & 10000 & 2015 & Canter Fe85 Pg6s 2p & 100 & 10.9 & 9.7 \\
\hline JBA5658 & 4000 & 2015 & Hfc 1035kd Ac 2p & 100 & 10.9 & 9.2 \\
\hline PCK9852 & 1498 & 2016 & Aveo Family Ac 1.5 4p & 45 & 5.1 & 5.1 \\
\hline PCM4778 & 2499 & 2014 & D-Max Td 2.5 Cs 4x2 & 76 & 10.9 & 13.9 \\
\hline PPA1095 & 2000 & 2010 & Grand Vitara Sz 2.01 5p & 66 & 13.52 & 12.5 \\
\hline PBY9821 & 1995 & 2012 & Grand Vitara Sz 2.01 5p & 66 & 13.52 & 12.5 \\
\hline PCA5408 & 1995 & 2012 & Grand Vitara Sz 2.01 5p & 66 & 13.52 & 12.5 \\
\hline PCN4355 & 2000 & 2015 & Sportage Lx Dab Ac 2.0 & 55 & 12.1 & 17.1 \\
\hline
\end{tabular}

Table 3. Distribution equipment

\subsection{Phase I. Diagnosis of the Transport Function within the Distribution System}

Step 1. Service level evaluation. To carry out the evaluation of the level of service that the company provides to its customers, it is necessary to start measuring Rancho Mary internally in the following manner:

- Number of deliveries made out of time

- Number of shipments that presented problems with quality and quantity.

With the records provided by the company, the level of service offered by the entity was calculated. The data to be used correspond to the year 2016 according to the criteria explained in Table 4. 


\begin{tabular}{|r|r|r|r|}
\hline \multicolumn{1}{|c|}{ Number of Orders } & $\begin{array}{c}\text { Orders Delivered Out of } \\
\text { Time (2016) }\end{array}$ & $\begin{array}{c}\text { Incomplete Delivered } \\
\text { Orders (2016) }\end{array}$ & Returned Orders (2016) \\
\hline 235 & 27 & 38 & 180 \\
\hline
\end{tabular}

Table 4. Level of service

Substituting in the reliability indicator gives the following:

$$
F=\left(1-\frac{27}{235} * 1-\frac{38}{235} * 1-\frac{180}{235}\right) * 100 \%=0.8851 * 0.8382 * 0.234=17.36 \%
$$

As can be observed, the logistics system presents a very low level of service, rising to $17.36 \%$, with particular emphasis on orders delivered out of time by $88.51 \%$, incomplete ones by $83.82 \%$ and those returned by $23.4 \%$, this being which most affects the deterioration of this indicator in general.

Fifty surveys were applied to different clients of the company and the following results were obtained generally:

- $60 \%$ of the requests are answered and there is a $40 \%$ existence of deficiencies in this indicator.

- $68 \%$ is in agreement with the offered offered however it is evident that it does not meet the expectations of our clients.

- $\quad$ The time required by the entity for the preparation of the contracts, reach customer satisfaction by $72 \%$; However, there is a low percentage that do not reach desired expectations, so you have to analyze the times required for the presentation of such document as this makes the customer can access an immediate credit.

Step 2. Evaluation of the main efficiency indicators. Economic indicators: In order to evaluate this indicator, the difference between the fuel consumed and the kilometers traveled for each equipment is taken into account.

Table 5 shows the actual fuel consumption used by equipment during the period 2016, which amounts to 4,173 liters in a general way. It should be noted that the company has not defined the fuel plan to be used for travel, but it is evident that there is a high consumption upwards approximately $5 \mathrm{~km}$ per liter.

\begin{tabular}{|c|r|r|r|}
\hline License plate & \multicolumn{2}{|c|}{$\begin{array}{c}\text { Total Planned Fuel } \\
\text { Consumption in Liters } \\
\text { (2016) }\end{array}$} & $\begin{array}{c}\text { Total Actual Fuel Consumption } \\
\text { in Liters (2016) }\end{array}$ \\
\hline PLQ0853 & 89960 & 256 & 351 \\
\hline PTB0776 & 104968 & 237 & 443 \\
\hline PCB7952 & 115082 & 238 & 484 \\
\hline JBA5567 & 95066 & 236 & 402 \\
\hline JBA5658 & 133639 & 120 & 1111 \\
\hline PCK9852 & 17992 & 298 & 60 \\
\hline PCM4778 & 41122 & 115 & 358 \\
\hline PPA1095 & 38574 & 149 & 259 \\
\hline PBY9821 & 36015 & 141 & 255 \\
\hline PCA5408 & 53976 & 148 & 364 \\
\hline PCN4355 & 107952 & 1269 & 85 \\
\hline Total & 834345 & 3208 & 4173 \\
\hline
\end{tabular}

Table 5. About Fuel Consumption 
The possible causes of this over consumption so high in the year are:

- There is no adequate control of kilometers traveled by vehicles

- That they were traveling more miles than planned so this would increase fuel consumption or,

- That the equipment for some technical defect is consuming more than norms.

Operational indicators:

Existing average equipment (Ee). It allows to know the amount of existing equipment that the company has in a period of time that is analyzed. The calculation showed that there are an average of 11 teams on average.

Average working equipment (Et). It expresses the number of equipment that on average work in the analyzed period of the total of existing equipment. This indicator showed that nine equipments were kept working.

1. Inactive average equipment: Indicates the amount of equipment that, on average, remains inactive (not working). On average, zero equipment were inactive during the year 2016.

2. Average equipment in repair: It allows to know the amount of equipment that on average are in repair and maintenance in the analyzed period. In the period were maintained in repair two equipment.

3. Coefficient of utilization of the equipment pool $\alpha$ a: With this indicator we can analyze the use of existing equipment within the park. The indicator showed that $81 \%$ of the park was used.

4. Technical availability coefficient $\alpha$ t: It expresses the degree of percentage disposition of the equipment to work, that is, the technically fit. During the period, $81 \%$ of equipment was suitable for use.

5. Coefficient of utilization of the static capacity (ysT): It expresses the degree of efficiency in which the nominal load capacity of an equipment is used. This indicator showed a value of $62 \%$, indicating that there is poor operational planning, which will be detected when the checklists are applied.

6. Coefficient of utilization of the dynamic capacity (ydin): It expresses the degree of efficiency which takes advantage of the load dynamics of an equipment. In this case these values correspond to the value of the utilization coefficient of the static capacity $62 \%$ since during the sampling period the equipment went to the same destinations.

7. Coefficient of utilization of the routes ( $\beta$ ): It is possible to analyze the degree to which the distance covered has been carried out with load. This analysis yielded a value of $59 \%$ since the equipment moves loaded mainly in one direction.

Step 3. Checklist evaluation. The evaluation of the checklists made to the personnel in charge of the logistics of Rancho Mary gave other elements to the diagnosis. To summarize, in the evaluation of the checklist some deficiencies were found in the following questions, giving a percentage of $50 \%$, which are listed below.

- Transportation needs do not immediately meet customer demand.

- There is no planning in the transport request.

- Technical conditions do not guarantee the protection and safety of personnel.

- There are not enough means of transport.

- They do not have operating manuals for transport management.

\subsection{Phase II: Evaluation of the Transport Function within the Distribution System}

As reflected in the aforementioned model, for the continuous improvement of the physical distribution, the characteristics of the products, the quantity to be distributed and the location of the destinations are taken into account, the rest of the functions are evaluated. These elements have already been treated in previous sections so it will continue describing how the definition of routes occurs.

Step 1. Definition of itineraries. In order to execute the transport plan, it is necessary to choose the most economical type of vehicle for each route, the correspondence of the type of vehicle with the character of the load transported and the conditions of operations. This is a precondition for the profitable use of transport. In this case 
the trucks will be selected as they are vehicles within the same category. The isocostal method shall be used for the selection of the means of transport.

\begin{tabular}{|r|r|r|r|r|c|}
\hline & \multicolumn{1}{|c|}{ PLQ0853 } & \multicolumn{1}{|c|}{ PTB0776 } & \multicolumn{1}{c|}{ PCB7952 } & \multicolumn{1}{c|}{ JBA5567 } & JBA5658 \\
\hline PLQ0853 & \multicolumn{1}{|c|}{$\mathrm{X}$} & & & & \\
\hline PTB0776 & -12.57 & $\mathrm{X}$ & & & \\
\hline PCB7952 & -7.29 & -7.37 & $\mathrm{X}$ & & \\
\hline JBA5567 & -10.04 & -13.33 & 2.21 & $\mathrm{X}$ & \\
\hline JBA5658 & -12.35 & -12.04 & -11.82 & 22.66 & $\mathrm{X}$ \\
\hline
\end{tabular}

Table 6. Distance Intersections with Fuel Consumption in Kilometers

As it can be seen in Table 6, negative intersections are discarded, on the other hand the smallest distance to which is transported is $2.21 \mathrm{Km}$ so that only the intersection of $22.66 \mathrm{~km}$ will be taken. As shown in Table 7, thus it can be concluded:

\begin{tabular}{|c|c|}
\hline Before the $22.66 \mathrm{~km}$ & After the $22.66 \mathrm{~km}$ \\
\hline JBA5658 & PLQ0853 \\
\hline JBA5567 & PTB0776 \\
\hline PCB7952 & PCB7952 \\
\hline PTB0776 & JBA5567 \\
\hline PLQ0853 & JBA5658 \\
\hline
\end{tabular}

Table 7. Optimal transportation

This is the order of priority to use the computers. As it can be seen, the latest equipment are the most expensive so if possible you will be dispensed with their services. For the design of the itineraries was based on the demand of each destination is well above the load capacity of the equipment, so a series of trips will be made to each destination (round trip) before grouping destinations.

As a first element, the quantity that can be transported in each type of equipment was calculated, based on the calculation of the volumetric capacity of each unit of load of the product and of the specific volumetric capacity of the equipment (see Tables 8 and 9):

\begin{tabular}{|r|r|r|r|r|r|}
\hline Gross weight $(\mathrm{Pb})$ & Volume & \multicolumn{1}{|c|}{ Length (l) } & a & \multicolumn{1}{|c|}{ Width (h) } & \multicolumn{2}{|c|}{ Vet } \\
\hline 0.045 & 0.252 & 1.2 & 0.6 & 0.35 & 5.6 \\
\hline
\end{tabular}

Note: Pb: gross weight. Vet: volumetric capacity of the product

Table 8 . Volumetric capacity of the product

\begin{tabular}{|r|r|r|}
\hline q (Tons) & \multicolumn{1}{|c|}{$\begin{array}{c}\text { Volumetric Capacity } \\
\text { (CW) }\end{array}$} & \multicolumn{2}{|c|}{$\begin{array}{c}\text { Capacity Volumetric } \\
\text { equipment (Cwe) }\end{array}$} \\
\hline 10 & 20.57 & 2.057 \\
\hline 6 & 20.57 & 3.4283 \\
\hline 4 & 20.57 & 5.1425 \\
\hline
\end{tabular}

Table 9. Volumetric capacity of the equipment 
As it can be seen, the product is lightweight for each type of equipment, both for 4, 6 or 10 ton equipment load capacity.

\begin{tabular}{|c|r|r|r|r|r|r|r|}
\hline & \multicolumn{1}{|c|}{$\mathrm{Pb} / \mathrm{q}$} & \multicolumn{1}{|c|}{ Volume/CW } & Vet/Cwe & Un & Nu-rec & Un-rec $*$ Pb & Static Sigma \\
\hline Products & 0.045 & 0.252 & 5.6 & & & & \\
\hline Equipment & 10 & 20.57 & 2.057 & 81.62 & 81 & 3.6 & 0.36 \\
\hline & 6 & 20.57 & 3.4283 & 81.62 & 81 & 3.6 & 0.6 \\
\hline & 4 & 20.57 & 5.1425 & 81.62 & 81 & 3.6 & 0.9 \\
\hline
\end{tabular}

Table 10. Coefficient of equipment utilization

In general, 81 bags of balanced feed can be transported. From the static sigma and the load capacity of the equipment, the number of trips for each destination was determined:

\begin{tabular}{|c|c|c|c|c|c|c|c|}
\hline Destinations & $\begin{array}{l}\text { Distance } \\
(\mathrm{Km})\end{array}$ & Demand & $\begin{array}{l}\text { Static } \\
\text { Sigma }\end{array}$ & $\mathbf{N v}$ & Days & $\mathrm{Ne}$ & $\begin{array}{l}\text { Remaining } \\
\text { amount }\end{array}$ \\
\hline Santo Domingo & 5.4 & 70 & 0.3645 & 19 & 5 & 0.1011 & 0.75 \\
\hline La Catorce & 60.3 & 80 & 0.3645 & 22 & 4 & 0.0998 & 0 \\
\hline Patricia Pilar & 40.3 & 90 & 0.3645 & 25 & 5 & 0.0988 & 0 \\
\hline Granjas & 50.9 & 100 & 0.3645 & 28 & 6 & 0.0980 & 0 \\
\hline El Carmen & 33 & 90 & 0.3645 & 24 & 5 & 0.1029 & 2.52 \\
\hline La Concordia & 44.8 & 80 & 0.3645 & 21 & 4 & 0.1045 & 3.46 \\
\hline Alluriquín & 58.4 & 60 & 0.3645 & 16 & 2 & 0.1029 & 1.68 \\
\hline San Gabriel & 14.6 & 30 & 0.3645 & 8 & 5 & 0.1029 & 0.84 \\
\hline Santa María del Toachi & 61.6 & 50 & 0.3645 & 14 & 4 & 0.0980 & 0 \\
\hline Valle Hermoso & 31.6 & 60 & 0.3645 & 17 & 4 & 0.0968 & 0 \\
\hline La Unión & 72.1 & 60 & 0.3645 & 16 & 3 & 0.1029 & 1.68 \\
\hline San Jacinto & 30.1 & 49 & 0.3645 & 13 & 2 & 0.1034 & 1.62 \\
\hline Nuevo Israel & 26 & 56 & 0.3645 & 15 & & 0.1024 & 1.33 \\
\hline Total & & 875 & & 238 & & 5 & 13.86 \\
\hline
\end{tabular}

Note: Nv: Number of trips; Ne: Number of equipments

Table 11. Load Capacity per Equipment

As can be seen, there are 13.86 tons remaining to be transported. For this amount the grouping of destinations will be done by the savings method. For the design of these itineraries we took into account the time restriction (8-hour workday) and the transportation capacity of each equipment.

Starting from the distances matrix, the savings matrix was made: 


\begin{tabular}{|c|r|r|r|r|r|r|r|r|}
\hline & $\begin{array}{c}\text { Santo } \\
\text { Domingo }\end{array}$ & \multicolumn{1}{|c|}{$\begin{array}{c}\text { El } \\
\text { Carmen }\end{array}$} & $\begin{array}{c}\text { La } \\
\text { Concordia }\end{array}$ & Alluriquín & $\begin{array}{c}\text { San } \\
\text { Gabriel }\end{array}$ & $\begin{array}{c}\text { La } \\
\text { Unión }\end{array}$ & $\begin{array}{c}\text { San } \\
\text { Jacinto }\end{array}$ & $\begin{array}{c}\text { Nuevo } \\
\text { Israel }\end{array}$ \\
\hline Santo Domingo & $\mathrm{X}$ & 33 & 43.7 & 58.4 & 14.6 & 32.6 & 30.1 & 31.3 \\
\hline El Carmen & 33 & $\mathrm{X}$ & 59.7 & 89.7 & 44.3 & 64.1 & 47.4 & 7.00 \\
\hline La Concordia & 43.7 & 59.7 & $\mathrm{X}$ & 94.9 & 54 & 69.1 & 29.1 & 50.4 \\
\hline Alluriquín & 57.4 & 89.9 & 95.1 & $\mathrm{X}$ & 58.2 & 25.8 & 85.7 & 82.7 \\
\hline San Gabriel & 14.6 & 44.3 & 59.9 & 58.2 & $\mathrm{X}$ & 34.6 & 40.1 & 37.3 \\
\hline La Unión & 32.6 & 64.1 & 69.1 & 25.8 & 34.6 & $\mathrm{X}$ & 59.9 & 57 \\
\hline San Jacinto & 30.1 & 47.4 & 29.1 & 85.6 & 40.1 & 59.9 & $\mathrm{X}$ & 21.3 \\
\hline Nuevo Israel & 31.3 & 7.00 & 50.4 & 82.7 & 37.3 & 57 & 21.3 & $\mathrm{X}$ \\
\hline
\end{tabular}

Table 12. Distances Matrix

\begin{tabular}{|c|r|r|r|r|r|r|r|r|}
\hline & \multicolumn{1}{|c|}{$\begin{array}{c}\text { Santo } \\
\text { Domingo }\end{array}$} & $\begin{array}{c}\text { El } \\
\text { Carmen }\end{array}$ & $\begin{array}{c}\text { La } \\
\text { Concordia }\end{array}$ & Alluriquín & $\begin{array}{c}\text { San } \\
\text { Gabriel }\end{array}$ & $\begin{array}{c}\text { La } \\
\text { Unión }\end{array}$ & $\begin{array}{c}\text { San } \\
\text { Jacinto }\end{array}$ & $\begin{array}{c}\text { Nuevo } \\
\text { Israel }\end{array}$ \\
\hline Santo Domingo & $\mathrm{X}$ & 102.2 & 44.8 & 79.8 & 14.6 & 43.3 & 73.9 & 95.2 \\
\hline El Carmen & 102.2 & \multicolumn{1}{|c|}{$\mathrm{X}$} & 59.7 & 89.7 & 44.3 & 64.1 & 47.4 & 7.00 \\
\hline La Concordia & 44.8 & 59.7 & $\mathrm{X}$ & 94.9 & 54 & 69.1 & 29.1 & 50.4 \\
\hline Alluriquín & 79.8 & 89.7 & 94.9 & $\mathrm{X}$ & 58.2 & 25.8 & 85.7 & 82.7 \\
\hline San Gabriel & 14.6 & 44.3 & 54 & 58.2 & $\mathrm{X}$ & 34.6 & 40.1 & 37.3 \\
\hline La Unión & 43.3 & 64.1 & 69.1 & 25.8 & 34.6 & $\mathrm{X}$ & 59.9 & 57 \\
\hline San Jacinto & 73.9 & 47.4 & 29.1 & 85.7 & 40.1 & 59.9 & $\mathrm{X}$ & 21.3 \\
\hline Nuevo Israel & 95.2 & 7 & 50.4 & 82.7 & 37.3 & 57 & 21.3 & $\mathrm{X}$ \\
\hline
\end{tabular}

Table 13. Savings Matrix
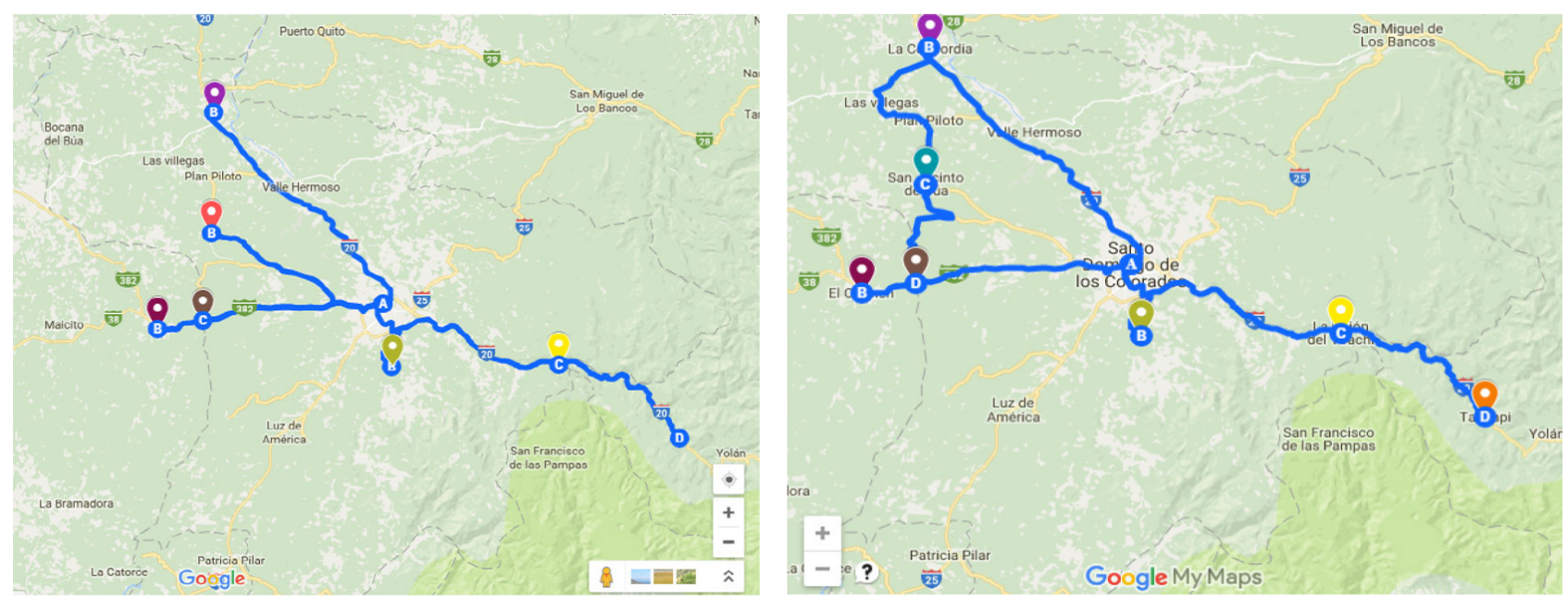

Figure 1. Current route maps

Figure 2 shows the route established by the entity. The truck (1) from Santo Domingo to San Jacinto, returning by the same road until arriving at New Israel, then continuing to El Carmen, to finally return to Santo Domingo in each place with a discharge time of 30 minutes; The truck (2) from Santo Domingo to Concordia and then returning to Santo Domingo with a 30 minute stop; The truck (3) from Santo Domingo to San Gabriel, returning 
to arrive to the Union of the Toachi and Alluriquín and finally to Santo Domingo, also has a discharge time of 30 minutes in each place. All this route makes a total of $288.8 \mathrm{~km}$ with 3 trucks of 4 tons.

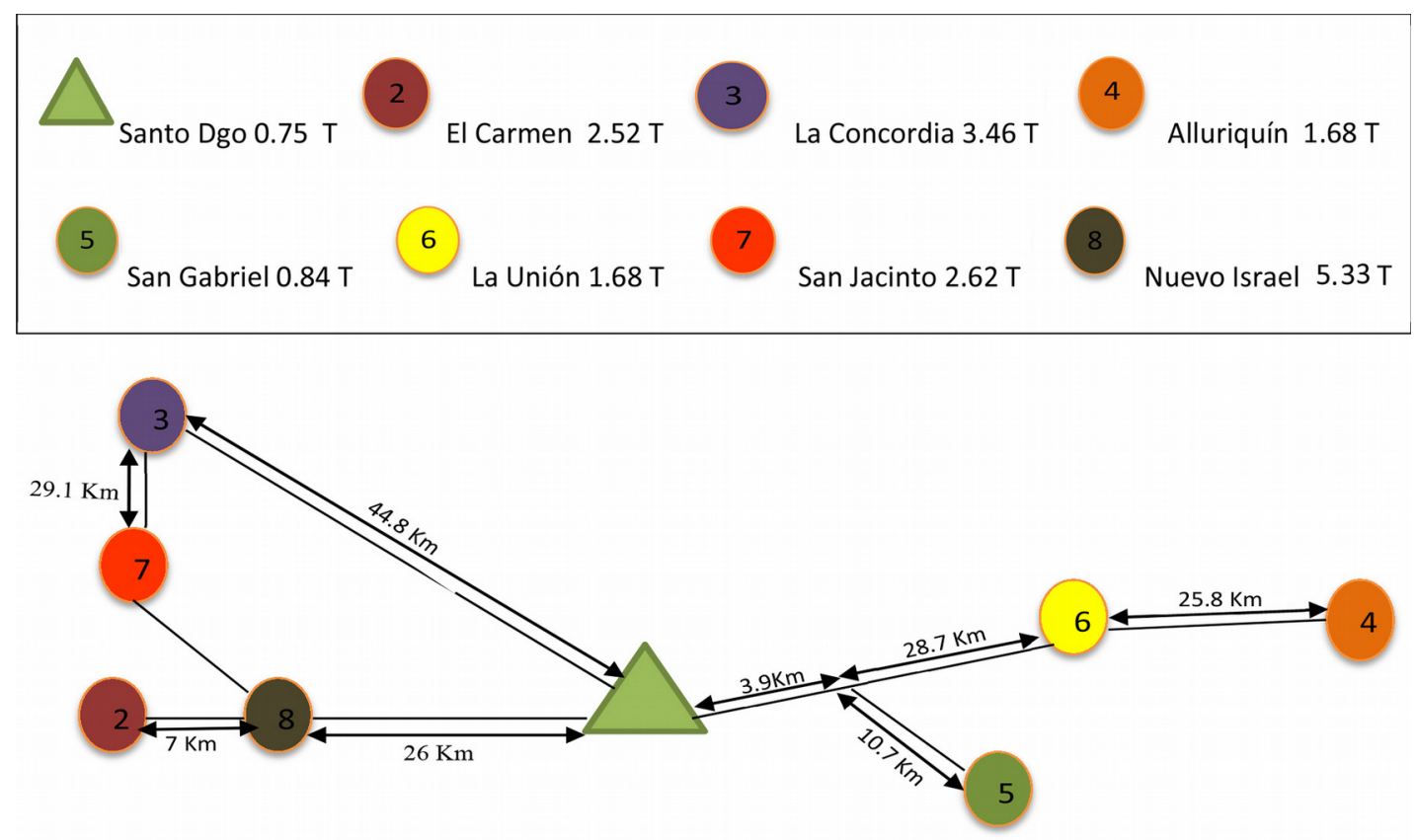

Figure 2. Improved route location graph

An improvement in the distribution of the routes is proposed, taking the following routes:

- First round trip, from Santo Domingo to La Concordia, San Jacinto, New Israel, El Carmen and return to Santo Domingo.

Calculation:

Total kilometers traveled $=(44.8+29.1+21.3+7+33)=135.2 \mathrm{Km}$

Time according to speed $(90 \mathrm{Km} / \mathrm{h})=\frac{135.2 \mathrm{Km}}{90 \mathrm{Km} / \mathrm{h}}=1.50 \mathrm{~h} * 60 \mathrm{~min} .=90 \mathrm{~min}$

Time of loading and unloading $(30 \mathrm{~min}$ in each place $)=150 \mathrm{~min}+90 \mathrm{~min}=240 \mathrm{~min}$

Time in hours $(240 \mathrm{~min}) /(60 \mathrm{~min} / \mathrm{h})=4$ hours

Total tons $=8.93$

- Second round trip, from Santo Domingo to San Gabriel, La Unión del Toachi, Alluriquín and return to Santo Domingo.

Calculation:

Total kilometers traveled $=(14.6+10.7+28.7+25.8+58.4)=138.2 \mathrm{Km}$

Time according to speed $(90 \mathrm{Km} / \mathrm{h})=\frac{138.2 \mathrm{Km}}{90 \mathrm{Km} / \mathrm{h}}=1.53 \mathrm{~h} * 60 \mathrm{~min} .=92.13 \mathrm{~min}$

Time of loading and unloading $(30 \mathrm{~min}$ in each place $)=150 \mathrm{~min}+92.13 \mathrm{~min}=242.13 \mathrm{~min}$

Time in hours $=\frac{242.13 \mathrm{~min}}{60 \mathrm{~min} / \mathrm{h}}=4$ hours

Total tons $=4.75$ 
As can be seen, from the previous distribution for the transport of leftovers $(13.86 \mathrm{~T})$, the following sequence will be obtained that generates the optimal path. What would be to assign a $10 \mathrm{~T}$ truck with a working day of 8 hours and a maximum travel speed of $90 \mathrm{~km}$ per hour: Santo Domingo - La Concordia, traveling $44.8 \mathrm{~km}$ with a stop of $30 \mathrm{~min}$ for a total of $3.46 \mathrm{~T}$; Following trip to San Jacinto at a distance of $29.1 \mathrm{Km}$, transporting $1.62 \mathrm{~T}$ with a discharge time of 30 minutes; To continue to New Israel at a distance of $21.3 \mathrm{~km}$, to download $1.33 \mathrm{~T}$; To continue to El Carmen with a distance of $7 \mathrm{~km}$ to download $2.52 \mathrm{~T}$, with a discharge time of 30 minutes; Finally return to Santo Domingo for a total time per tour of 4 hours.

This same truck is loaded again with $4.75 \mathrm{~T}$ and will begin the tour in the city of Santo Domingo to download 0.75 T with a discharge time of $30 \mathrm{~min}$; To follow San Gabriel with a distance of $14.1 \mathrm{~km}$, transporting $0.84 \mathrm{~T}$ in a stop of 30 minutes, turning to reach the main route, traveling $10.7 \mathrm{~km}$; The journey continues to arrive at the Union of the Toachi, crossing $28.7 \mathrm{~km}$ to download $1.62 \mathrm{~T}$ in a time of 30 minutes; Arrives at its destination Alluriquín with a route $25.8 \mathrm{~km}$ to download $1.68 \mathrm{~T}$ in 30 minutes; Finally returns to Santo Domingo, making a total time for 4 hours tour and fulfilling the working day.

The operational planning is shown in Table 14, where 1 equipment was needed to carry out the transportation. A summary of the main results with the new planning is shown below:

\begin{tabular}{|c|r|r|}
\hline & New alternative & Old alternative \\
\hline $\mathrm{Ne}$ & 1 & 3 \\
\hline $\mathrm{Nv}$ & 2 & 3 \\
\hline $\mathrm{Q}$ & $13.86 \mathrm{kons}$ & 13.86 tons \\
\hline Total Distance & $240.4 \mathrm{~km}$ & $288.8 \mathrm{~km}$ \\
\hline $\mathrm{q}$ & 10 tons & 4 tons \\
\hline Consumption (liter $/ 100 \mathrm{~km})$ & 10.9 & 9.7 \\
\hline Saving in liters & 26.2 & 84 \\
\hline
\end{tabular}

Table 14. Operational planning

Following the logic of the previous organization, it can be stated that weekly fuel consumption is reduced by 57.81 liters, in addition to giving a better use to the routes made with load to each vehicle.

Transportation needs. The means of transport used in the distribution yielded a value of 8 , which is below the current equipment park (11), so it is sufficient.

\section{Conclusions}

The theoretical review allowed the identification of the main limitations of the logistic evaluation of the transport, while contributing with the holistic technology proposal for the management of this process, which integrates indicators and tools that improve the control and decision-making activities in this area.

When the evaluation system was implemented in the company under analysis, specifically in the transport function, it was detected that the availability of the equipment does not respond to the needs of the customers and there is no procedure to know the use of the capacity of the vehicles of load in the transport, being observed like main consequences the economic losses and the dissatisfaction of the customers.

The main functions of physical distribution were redesigned, such as route planning, selection of means of transport and analysis of operating indicators, which contributed to the optimization of the number of trips and consequently the adequate use of the park of equipment and loads to be transported, with a saving of $15 \%$ in the fuel consumption per load transported. 


\section{Declaration of Conflicting Interests}

The authors declared no potential conflicts of interest with respect to the research, authorship, and/or publication of this article.

\section{Funding}

The authors received no financial support for the research, authorship, and/or publication of this article.

\section{References}

Afonso, P., \& Santana, A. (2016). Application of the TDABC model in the logistics process using different capacity cost rates. Journal of Industrial Engineering and Management, 9(5), 1003. https://doi.org/10.3926/jiem.2086

Altendorfer, S., \& Zsifkovits, H. (2016). Lab-Enriched Logistics Education-Current Status and Future Opportunities at the Example of the Chair of Industrial Logistics at the Montanuniversität Leoben. In Dynamics in Logistics (609-615). Springer International Publishing.. https://doi.org/10.1007/978-3-319-23512-7_59

Ayala-Bécquer, P., Bustillo-González, I., \& Sánchez-Fernández, R. (2001). Auditorías Logísticas: Un Nuevo Enfoque en el Control. III Jornada Científica Nacional del CID - CI. La Habana.

Ballou, R. (1991). Logística Empresarial. Controly Planificación (24-39). Madrid. España. Ediciones Días de Santos, SA.

Carrasco, J., Mataix, C., \& Carrasco-Gallego, R. (2017). Organizational Engineering: The Emerging Stage of Industrial Engineering. In Engineering Systems and Networks (347-354). Cham: Springer.

Cespón-Castro, R., \& Auxiliadora-Amador, M. (2003). Administración de la Cadena de Suministro. Manual para estudiantes de la especialidad de Ingeniería Industrial. Tegucigalpa: Universidad Tecnológica Centroamericana, UNITEC.

Chang, S.H., \& Lin, C.Y. (2016). A Visible Light Communication Positioning Mechanism in Industrial Logistics Management. In Advanced Information Networking and Applications Workshops (WAINA), 30th International Conference. IEEE. 878-882. https://doi.org/10.1109/WAINA.2016.175

Chase, R.B., Jacobs, F.R., \& Aquilano, N.J. (2009). Administración de Operaciones: Producción y Cadena de Suministros. (12th ed.). México: Editorial McGraw-Hill.

Fahimnia, B., Reisi, M., Paksoy, T., \& Özceylan, E. (2013). The implications of carbon pricing in Australia: An industrial logistics planning case study. Transportation Research Part D: Transport and Environment, 18, 78-85. https://doi.org/10.1016/j.trd.2012.08.006

Heizer, J., \& Render, B. (2009). Principios de administración de operaciones (7th ed.). México: Pearson Education.

Krajewski, W. (2012). Correspondence principle and growth of science, 4. Springer Science \& Business Media.

Lee, C.K.M., \& Lam, J.S.L. (2012). Managing reverse logistics to enhance sustainability of industrial marketing. Industrial Marketing Management, 41(4), 589-598. https://doi.org/10.1016/j.indmarman.2012.04.006

Magee, J.F. (1968). Industrial logistics. McGraw-Hill.

Martínez-Vivar, R., Sánchez-Rodríguez, A., García-Vidal, G., \& Pérez-Campdesuñer, R. (2016). Gestión de las reservas productivas en una PYME de Santo Domingo de los Tsáchilas. Enfoque UTE, 7(1), 59. https://doi.org/10.29019/enfoqueute.v7n1.88

Mimouni, F., \& Abouabdellah, A. (2016). Proposition of a modeling and an analysis methodology of integrated reverse logistics chain in the direct chain. Journal of Industrial Engineering and Management, 9(2), 359. https://doi.org/10.3926/jiem.1720

Movahedipour, M., Yang, M., Zeng, J., Wu, X., \& Salam, S. (2016). Optimization in supply chain management, the current state and future directions: A systematic review and bibliometric analysis. Journal of Industrial Engineering and Management, 9(4), 933. https://doi.org/10.3926/jiem.2035 
Raza, T., Lang, W., \& Jedermann, R. (2017). Integration of Wireless Sensor Networks into Industrial Control Systems. In Dynamics in Logistics (209-218). Springer International Publishing.. https://doi.org/10.1007/978-3-31945117-6_19

Stoner, J.A.F. (1996). Administración (6th ed.). Prentice-Hall Hispanoamericana, SA.

Swink, M., Melnyk, S.A., Cooper, M.B., \& Hartley, J. L. (2014). Managing Operations: Across the Supply Chain (248-249). New York, NY: McGraw-Hill/Irwin.

Vélez, A. (1996). La Simbiosis Obligada. Rev. Manutención y Almacenaje, 31(304 marzo). Cetisa Boixareu Editores, SA Barcelona, 51.

\section{Journal of Industrial Engineering and Management, 2018 (www.jiem.org)}

\section{(ब) $(1)$}

Article's contents are provided on an Attribution-Non Commercial 4.0 Creative commons International License. Readers are allowed to copy, distribute and communicate article's contents, provided the author's and Journal of Industrial Engineering and Management's names are included. It must not be used for commercial purposes. To see the complete license contents, please visit https://creativecommons.org/licenses/by-nc/4.0/. 